\title{
The Effects of Banking Regulation on Asset Quality: A Panel Analysis
}

\author{
Nader Alber ${ }^{1}$ \\ ${ }^{1}$ Faculty of Commerce, Ain Shams University, Cairo, Egypt \\ Correspondence: Nader Alber, Faculty of Commerce, Ain Shams University, Cairo, Egypt. Tel: 201-005-668-507. \\ E-mail: naderalberfanous@yahoo.com
}

Received: April 25, 2014

Accepted: May 26, 2014

Online Published: June 25, 2014

doi:10.5539/ibr.v7n7p164

URL: http://dx.doi.org/10.5539/ibr.v7n7p164

\begin{abstract}
This paper attempts to investigate the effects of banking regulation on asset quality. This has been conducted using a sample of 14 countries from 1) Middle East \& Africa, 2) Europe \& Central Asia, 3) Latin America \& Caribbean and 4) East Asia \& Pacific, over the period from 2006 to 2012.

Asset quality is measured by "bank nonperforming loans to gross loans" according to The World Bank database regarding World Development Indicators, while banking regulation is measured by the "response to Basel implementation" according to FSI survey of July 2013.

Results indicate that implementation of SA "Standardized Approach" and Conserv "Capital conservation buffer" may affect "asset quality" for low-asset quality countries (Middle East \& Africa and Europe \& Central Asia groups), while implementation of BIA "Basic indicator approach " and P2 "Pillar2" may affect "asset quality" for high-asset quality ones (Latin America \& Caribbean and East Asia \& Pacific groups).
\end{abstract}

Keywords: asset quality, banking regulation, panel analysis

\section{Introduction}

Early attempts to measure banks' performance using CAMEL approach abound in the literature from Beaver (1966) and Altman (1968) to Maishanu (2004), Wirnkar \& Tanko (2008), Tatom \& Houston (2011) and Njoku (2012).

CAMEL approach rates the performance of banks along five key dimensions: capital adequacy, asset quality, management, earnings, and liquidity. Most efforts focuse on capital adequacy, liquidity, and earnings. Capital adequacy and liquidity deserve their importance as regulatory constraints, while earnings deserves its importance as a major objective. Asset quality and management have less attention from scholars in this field, while asset quality is a main indicator of "management quality" and management is behind good and bad decisions that affect other CAMEL aspects.

The motivation of this paper is based on two points:

- The lack of papers concerning with asset quality, compared with other CAMEL aspects. Addressing CAMEL as CLEAM reflects the importance of each component (from academic and practical perspectives) in descending order. So, this means that asset quality is the second uncovered components.

- The importance of asset quality as a main determinant of earnings and a main output of credit decisions.

Asset quality could be considered as a milestone within CAMEL approach, as it represents "management quality" and affects earnings, within capital adequacy and liquidity constrains.

Table (1) shows descriptive statistics of asset quality as measured by "bank non-performing loans to gross loans" for a sample of 14 countries from 1) Middle East \& Africa, 2) Europe \& Central Asia, 3) Latin America \& Caribbean and 4) East Asia \& Pacific, over the period from 2006 to 2012. 
Table 1. Descriptive statistics of non-performing loans ratio

\begin{tabular}{lcccc}
\hline Category & Min. & Max. & Mean & S. Dev. \\
\hline Middle East\& Africa & 0.0200 & 0.1930 & 0.0728 & 0.0447 \\
Europe\& Central Asia & 0.0050 & 0.1900 & 0.0718 & 0.0625 \\
Latin America\& Caribbean & 0.0080 & 0.0410 & 0.0203 & 0.0095 \\
East Asia\& Pacific & 0.0030 & 0.0750 & 0.0293 & 0.0202 \\
\hline All Sample & 0.0030 & 0.1930 & 0.0543 & 0.0472 \\
\hline
\end{tabular}

Source: collected and processed by the researcher.

Table (1) illustrates that assets quality of banks in Middle East \& Africa and Europe \& Central Asia is worse than that of Latin America \& Caribbean and East Asia \& Pacific banks. This could be noticed by comparing non-performing loans ratios of the first category (ranged from $7.18 \%$ to $7.28 \%$ ) with those of the second category (ranged from $2.03 \%$ to $2.93 \%$ ).

The importance of asset quality may motivate the analysis of its regulatory determinants. This paper tries to investigate the effects of banking regulation on asset quality where banking regulation is measured by "response to Basel implementation" according to FSI survey on July 2013.

The paper is arranged as follows: after this introduction, section 2 addresses the recent developments in banking regulation. Section 3 reviews research literature that has concerned with "banking regulation" and "asset quality", while Section 4 explains how to measure research variables and investigates how to test the research hypothesis. Section 5 illustrates the empirical work, and Section 6 summarizes the paper and provides remarks about conclusions.

\section{Recent Developments in Banking Regulation}

Capital of banks has been related to risk, for the extent that make us see that the function of capital in banks is to absorb banking operations risks. As financial intermediaries, banks have, not only their risks, but also risks of other firms.

In the early seventies of the last century, many banks had been bankrupt, and many others had not acceptable levels of capital adequacy. For these reasons "Basle Committee" aimed to develop a unified standard for measuring bank capital adequacy. Basle accord began in 1975, and was modified in 1983 under supervision of International Settlement Bank. In Dec. 10, 1987, the Committee decided that capital adequacy ratio should be $7.25 \%$ as a minimum at the end of 1989 , and $8 \%$ at the end of 1992 . The Committee determined the components of the ratio, where its numerator includes core capital and supplementary capital, and its dominator includes 4 categories representing 4 levels of risk (Sinkey, 2002, p. 271), where each level was weighted according to its level of risk, from 0 to $20 \%$, to $50 \%$, to $100 \%$ as risk level increases.

In 1993, the Committee suggested to add a third category to the capital. This category includes subordinated debt, which cover market risk only through issuing bonds at a rate exceeding the market rate. In Dec., 11, 1995, the central banks governors of the G10 accepted this agreement, and decided application before 1998. It seems that the first ratio issued in 1988 hasn't been sensitive to banking risks, even after modification of 1998. This leads "Basle II", which includes 3 major dimensions: the first is the minimum requirements of capital, the second is the auditing control, and the third is market discipline (Saunders \& Cornett, 2003, 524; Pujal, 2001, pp. 36-39).

Spina (2013) elaborates how Basel III presents substantial improvement upon previous versions by requiring an increase in the quantity and quality of capital. Although the nominal capital requirement continues to be $8 \%$ of risk-weighted assets, as in Basel I and II, the new rules specify that at least $75 \%$ of the total capital must be Tier 1 Capital, thus $25 \%$ in Tier 2 Capital (as opposed to 50/50 prescribed in previous versions). Furthermore, Tier 1 is divided into two categories, Common Equity Tier 1 (at least $4.5 \%$ of a bank's RWA), and Additional Tier 1 (generally preferred stock and additional paid-in capital that otherwise does not satisfy the criteria for Tier 1).

Basel III introduces a new global framework for liquidity regulation. One part of this framework is the liquidity coverage ratio (LCR), which requires banks to hold sufficient high-quality liquid assets to survive a 30-day period of market stress. Beck.\& Keister (2013) shows that if banks face the possibility of an LCR shortfall, then the usual link between open market operations and the overnight interest rate changes and the short end of the yield curve becomes steeper. 
Basel Committee on Banking Supervision (3013, p. 4) addresses that the core components of the Basel III were finalized in 2011, where the capital frameworks for global and domestic systemically important banks (G-SIBs and D-SIBs) were published in 2011 and 2012 respectively. The Committee issued the final standard for the Liquidity Coverage Ratio in January 2013, with implementation scheduled to commence in 2015. Table (2) illustrates these implementations.

Table 2. Status of Basel III components and target dates for implementation

\begin{tabular}{ll}
\hline Core component of Basel III & Progress \\
\hline Basel III capital adequacy reforms Published in 2011 & implementation from 1 January 2013 \\
G-SIB/D-SIB framework Published in 2011 and 2012 & implementation 1 January 2016 \\
Liquidity Coverage Ratio Published in 2013 & implementation from 1 January 2015 \\
Leverage ratio & disclosure starting in 2015 with a view to migrate to Pillar 1 in 2018 \\
Net Stable Funding Ratio & under review; minimum standard to be introduced in 2018 \\
\hline
\end{tabular}

Source: Basel Committee on Banking Supervision (3013, p. 4).

Empirical literature on banking regulations and banking stability has taken two main directions. The first is called implicit-fragility method that uses implicit measures of fragility such as: the ratio of non-performing loan on the total asset, bank stock price volatility, and the ratio of risk-weighted assets to total assets; while the explicit-fragility method uses the occurrence of a systemic banking crisis in a given economy as an explicit measure of instability. These two methods differ also in terms of econometric techniques that they use for their estimations. The implicit-fragility method relies mainly on simultaneous equation models, and on the survival and/or hazard models; while the explicit-fragility method relies on the discrete regression model such as logit or probit in the context of panel data (Tchana, 2008, pp. 33-34)

Schinasi (2004) addresses that financial stability relates not only to the absence of financial distress but also to the capability of the financial system to limit, contain, and deal with such situations. Schinasi (2006) addresses "stability" as the ability of financial system to resolve systemic risks. He argues that financial system is stable if the system is capable to perform three key functions: 1) allocation of resources from savers to investors; 2) assessment, pricing, and allocation of financial risks and 3) absorption of financial and economic shocks.

Banking regulation aims at enhancing financial stability, and this is why, many global, regional and governmental bodies are established for its promotion. The Financial Stability Board (FSB) is established to address financial system susceptibilities and to drive the development and implementation of strong regulatory, supervisory, and other policies which enhance financial stability. Also, the Financial Stability Forum (FSF) has been set up by the G-7 in the wake of the Asian crisis in 1999, with an expanded membership (drawn mainly from the G-20).

In US, the legislation Restoring American Financial Stability Act of 2010 focuses on how to promote the financial stability. The UK Financial Services Authority (FSA) requires stricter capital rules than those proposed by the Basel Committee on Banking Supervision (BCBS). The European Central Bank (ECB) is in charge of monitoring and assessment of financial stability. Presently, the Committee of European Banking Supervisors (CEBS) provides regular bank sector analysis, performs assessments on banking risks, to be reported to the European Union political institutions.

\section{Literature Review}

This section tries to present some of previous work, which has been conducted in two fields: 1) banking regulation and 2) asset quality.

Regarding banking regulation (of individual banks), Barth et al. (2008) presents survey information on bank regulations in 142 countries and shows that meeting capital requirements doesn't necessarily enhance stability or efficiency. Demirgüç-Kunt \& Detragiache (2011) uses data for more than 3000 banks in 86 countries and addresses that compliance with the Basel core principles doesn't affect bank risk measured by Z-scores.

De Nicolò et al. (2011) analyzes the impact of capital regulation, liquidity requirements and taxation on banks' optimal policies and metrics of efficiency of intermediation and social value. Results indicate that mild capital requirements increase bank lending, bank efficiency and social value relative to an unregulated bank. Also, 
findings show that liquidity requirements reduce bank lending, efficiency and social value significantly.

Banking regulation aims at enhancing financial stability that may affect banking market structure. Literature - in this context - elaborates regulatory effects, not only at for individual banks, but also for the banking system.

Regarding banking regulation (of banking systems), Schaeck et al. (2007) investigates the implications of competitive bank behavior with 38 countries for the period 1980-2003. They find that competition reduces the likelihood of a crisis and increases time to observing crisis. Berger et al. (2009) supports the "competition-fragility" view using over 8235 banks in 23 developed countries for the years 1999-2005. Besides, Uhde \& Heimeshoff (2009) analyzes over 2600 banks across the EU-25 during the period from 1997 to 2005 and their empirical results are consistent with the "concentration-fragility" view.

Amidu \& Wolfe (2009) analyzes a panel dataset of 978 banks, during the period 2000-2007. The authors use $\mathrm{H}$-statistic and the Lerner index as measures of the degree of competition in the banking sector, employ three stage least squares (3sls) estimation techniques, and investigate the significance of diversification in the competition-stability relationship. The core finding is that competition increases stability as diversification across and within both interest and non-interest income generating activities of banks increases.

Swamy (2011) analyzes the determinants of banking sector soundness, as measured by banking stability index (BSI) in the context of an emerging economy banking sector. This study considers the core set of soundness indicators for the construction of the index for the Indian financial system during the period 1997-2009.

Dobravolskas \& Seiranov (2011) investigates the reasons of financial instability, during the 2007-2008 crisis and studies the ways of rebuilding financial stability in the process of post-crisis regulatory reforms. Findings show that violation of stability is a result of deregulation processes in major financial markets since 1980s on the one hand, a result of inadequacy of national micro-prudential regulators on the other hand. The article studies how these targets are met in post-crisis regulatory reforms, in USA, the European Union and Lithuania.

Buston (2012) shows the net impact of two opposing effects of active risk management at banks on their stability. This has been applied on US BHCs using a sample of an unbalanced panel containing 7253 observations and 2276 banks, from 2005 to 2010. Empirical evidence supports the effects of active risk management at banks on their stability and show that active risk management banks are less likely to fail during the crisis of 2007-2009.

Wen \& Yu (2013) elaborates the effects of bank stability on market concentration, financial deepening, bank income structure and international debt situation by using panel data for 18 emerging countries. Results supports that concentration affects financial stability in banking industry.

Schaeck \& Cihak (2013) indicates that competition robustly improves stability via the efficiency channel, for banks from 10 European countries during the period 1995-2005. The sample consists of 17965 bank-year observations for 3325 banks.

Concerning with Asset Quality, Acharya et al. (2009) shows that market freezes depend on how information about asset quality is revealed. They illustrate that when there is a constant probability that "bad news" is revealed each period and, in the absence of bad news, the value of the assets is high. By contrast, for the "good news", the value of the assets is low.

Beck et al (2013) uses three indicators of asset quality: 1) maturity matching, 2) loan loss provisions, and 3) non-performing loans. As indicators of bank stability, the paper uses 1) maturity matching, the ratio of liquid assets to deposit and short-term funding to assess the sensitivity to bank runs. 2) equity to assets ratio, and 3) return on assets. The paper analyzes the differences in efficiency, asset quality, and stability of Islamic and conventional banks across a sample of 22 countries with both types of institutions during the period from 1997 to 2010. Empirical estimations show that Islamic banks are less efficient, but have higher intermediation ratios, have higher asset quality, and are better capitalized than conventional banks.

Swamy (2013) investigates the determinants of asset quality of Indian banks using panel data for the period from 1997-2009. The findings of the study show that asset quality is affected by industry characteristics, macroeconomic conditions, size and ownership of banks.

Pastory \& Mutaju (2013) investigates the relationship between the capital adequacy and asset quality of commercial the banks in Tanzania, using panel data from 33 banks in the period (2006-2011). The findings indicate that capital adequacy has a great influence on the asset quality. The increase in capital ratios has sometimes reduced the asset quality productivity and in most cases the levels of non-performing loans and non-performing asset have been increased with the increase in capital ratios.

Comparing with previous work, the current study tries to: 
- Investigate the effects of actual implementations 3 categories of Basel agreements, while previous work tend to address them without these detailed techniques.

- Concern with asset quality as an important dimension of CAMEL approach that hasn't an adequate attention, compared with other dimensions.

\section{Data Description and Hypotheses Developing}

Required data regarding "banking regulations" indicators are collected from FSI Survey- Basel II, 2.5 and III Implementation (www.bis.org/fsi/fsiop2013.pdf). Tables (3), (4) and (5) show these implementations in 2 categories (final rule is in force and otherwise) while the original report categorizes implementation into 5 categories (Final rule in force, Final rule published, Draft regulation published, Draft regulation not published, Not applicable).

Table 3. Indicators of "Basel II" implementation

\begin{tabular}{llc}
\hline \multicolumn{1}{c}{ Variable } & $=1$ if final rule is in force and $=0$ for otherwise \\
\hline Standardized approach, & $=1$ if final rule is in force and $=0$ for otherwise \\
Foundation internal ratings-based approach & $=1$ if final rule is in force and $=0$ for otherwise \\
Advanced internal ratings-based approach & $=1$ if final rule is in force and $=0$ for otherwise \\
Basic indicator approach & $=1$ if final rule is in force and $=0$ for otherwise \\
Standardized/alternative standardized approach & $=1$ if final rule is in force and $=0$ for otherwise \\
Advanced measurement approaches & $=1$ if final rule is in force and $=0$ for otherwise \\
Pillar 2 & $=1$ if final rule is in force and $=0$ for otherwise \\
Pillar 3 & BIA
\end{tabular}

Source: www.bis.org/fsi/fsiop2013.pdf.

Table 4. Indicators of "Basel 2.5" implementation

\begin{tabular}{lll}
\hline \multicolumn{1}{c}{ Variable } & \multicolumn{1}{c}{ Calculation } \\
\hline Revisions to Pillar 1 & $=1$ if final rule is in force and $=0$ for otherwise \\
Supplemental Pillar 2 guidance & $=1$ if final rule is in force and $=0$ for otherwise \\
Revisions to Pillar 3 & $=1$ if final rule is in force and $=0$ for otherwise \\
Revisions to Basel II market risk framework & SupplP2
\end{tabular}

Source: www.bis.org/fsi/fsiop2013.pdf.

Table 5. Indicators of "Basel III" implementation

\begin{tabular}{ll}
\hline \multicolumn{1}{c}{ Variable } & \multicolumn{1}{c}{ Calculation } \\
\hline Liquidity standard & $=1$ if final rule is in force and $=0$ for otherwise \\
Definition of capital & $=1$ if final rule is in force and $=0$ for otherwise \\
Risk coverage & $=1$ if final rule is in force and $=0$ for otherwise \\
Capital conservation buffer & $=1$ if final rule is in force and $=0$ for otherwise \\
Countercyclical capital buffer & $=1$ if final rule is in force and $=0$ for otherwise
\end{tabular}

Source: www.bis.org/fsi/fsiop2013.pdf.

NPLoans denotes "bank non-performing loans to gross loans" as an indicator for "Asset Quality" and it's measured by dividing non-performing loans on gross loans, according to database of World Development Indicators, published by The World Bank http://data.worldbank.org/indicator/FB.AST.NPER.ZS.

This paper aims at testing the following main hypothesis: There is no significant effect of "Basel requirements" 
implementation on banks' "asset quality". This hypothesis, could be tested as follows:

1) Regarding implementation of Basel II:

$$
N P \text { Loans }=\alpha+\beta_{1} S A+\beta_{2} F I R B+\beta_{3} A I R B+\beta_{4} B I A+\beta_{5} T S A+\beta_{6} A M A+\beta_{7} P 2+\beta_{8} P 3
$$

For each of "Basel requirements" implementation, the null hypothesis H0 could be shown as:

$$
\beta_{n}=0(\text { where } n=1,2,3 \text { to } 8)
$$

The alternative hypothesis Ha could be shown as:

$$
\beta_{n} \neq 0(\text { where } n=1,2,3 \text { to } 8)
$$

2) Regarding implementation of Basel 2.5:

$$
\text { NPLoans }=\alpha+\beta_{9} \operatorname{RevP1}+\beta_{10} \text { SupplP2 }+\beta_{11} \operatorname{RevP} 3+\beta_{12} \text { MktRisk }
$$

For each of "Basel requirements" implementation, the null hypothesis $\mathrm{H} 0$ could be shown as:

$$
\beta_{n}=0(\text { where } n=9,10,11,12)
$$

The alternative hypothesis Ha could be shown as:

$$
\beta_{n} \neq 0(\text { where } n=9,10,11,12)
$$

3) Regarding implementation of Basel III:

$$
\text { NPLoans }=\alpha+\beta_{13} \text { Liq }+\beta_{14} \text { DefCap }+\beta_{15} \text { RiskCov }+\beta_{16} \text { Conserv }+\beta_{17} \text { C-cycl }
$$

For each of "Basel requirements" implementation, the null hypothesis $\mathrm{H} 0$ could be shown as:

$$
\beta_{n}=0(\text { where } n=13,14 \text { to } 17)
$$

The alternative hypothesis Ha could be shown as:

$$
\beta_{n} \neq 0(\text { where } n=13,14 \text { to } 17)
$$

4) Regarding implementation of Basel II, 2.5 and III:

$$
\begin{aligned}
& \text { NPLoans }=\alpha+\beta_{1} S A+\beta_{2} \text { FIRB }+\beta_{3} \text { AIRB }+\beta_{4} \text { BIA }+\beta_{5} \text { TSA }+\beta_{6} A M A+\beta_{7} P 2+\beta_{8} P 3+\beta_{9} \text { RevP1 }+\beta_{10} \\
& \text { SupplP2 }+\beta_{11} \text { RevP } 3+\beta_{12} \text { MktRisk }+\beta_{13} \text { Liq }+\beta_{14} \text { DefCap }+\beta_{15} \text { RiskCov }+\beta_{16} \text { Conserv }+\beta_{17} \text { C-cycl }
\end{aligned}
$$

For each of "Basel requirements" implementation, the null hypothesis H0 could be shown as:

$$
\left.\beta_{n}=0 \text { (where } n=1,2,3 \text { to } 17\right)
$$

The alternative hypothesis Ha could be shown as:

$$
\beta_{n} \neq 0(\text { where } n=1,2,3 \text { to } 17)
$$

\section{Results of Empirical Study}

Required data include the implementation of banking regulations (14 items, shown in table 6) and asset quality (measured by non-performing loans ratio) during the period from 2006 to 2012. This has been conducted for a sample of 14 countries, where the first group includes Egypt, United Arab Emirates, Kuwait, Lebanon, Morocco and Mauritius, the second one includes Bosnia and Herzegovina, Norway and Serbia, the third one includes Chile, Peru and Panama and the fourth one includes New Zealand and Philippines.

These countries represent 4 groups, (Middle East \& Africa, Europe \& Central Asia, Latin America \& Caribbean and East Asia \& Pacific). The following table illustrates descriptive statistics of these data for each of the 4 regions covered in this study and for the study sample as a whole: 
Table 6. Descriptive statistics of banking regulation and asset quality indicators

\begin{tabular}{lccccccccccccc}
\hline \multirow{2}{*}{ Variables } & \multirow{2}{*}{ Min } & \multirow{2}{*}{ Max } & \multicolumn{3}{c}{ Middle East \& Africa } & \multicolumn{3}{c}{ Europe \& Central Asia L. America \& Caribbean } & \multicolumn{3}{c}{ East Asia \& Pacific } & \multicolumn{2}{c}{ All Sample } \\
\cline { 5 - 13 } & & & Mean & S. Dev. & Mean & S. Dev. & Mean & S. Dev. & Mean & S. Dev. & Mean & S. Dev. \\
\hline SA & 0.00 & 1.00 & 0.67 & 0.477 & 0.38 & 0.498 & 0.24 & 0.436 & 0.71 & 0.469 & 0.52 & 0.502 \\
FIRB & 0.00 & 1.00 & 0.64 & 0.485 & 0.38 & 0.498 & 0.24 & 0.436 & 0.71 & 0.469 & 0.51 & 0.502 \\
BIA & 0.00 & 1.00 & 0.60 & 0.497 & 0.57 & 0.507 & 0.19 & 0.402 & 0.79 & 0.426 & 0.53 & 0.502 \\
TSA & 0.00 & 1.00 & 0.52 & 0.505 & 0.38 & 0.498 & 0.19 & 0.402 & 0.43 & 0.514 & 0.41 & 0.494 \\
AMA & 0.00 & 1.00 & 0.02 & 0.154 & 0.38 & 0.498 & 0.24 & 0.436 & 0.36 & 0.497 & 0.19 & 0.397 \\
P2 & 0.00 & 1.00 & 0.57 & 0.501 & 0.38 & 0.498 & 0.00 & 0.000 & 0.50 & 0.519 & 0.40 & 0.492 \\
P3 & 0.00 & 1.00 & 0.55 & 0.504 & 0.38 & 0.498 & 0.00 & 0.000 & 0.79 & 0.426 & 0.43 & 0.497 \\
RevP1 & 0.00 & 1.00 & 0.07 & 0.261 & 0.10 & 0.301 & 0.00 & 0.000 & 0.00 & 0.000 & 0.05 & 0.221 \\
SupplP2 & 0.00 & 1.00 & 0.17 & 0.377 & 0.10 & 0.301 & 0.00 & 0.000 & 0.07 & 0.267 & 0.10 & 0.304 \\
RevP3 & 0.00 & 1.00 & 0.02 & 0.154 & 0.10 & 0.301 & 0.00 & 0.000 & 0.00 & 0.000 & 0.03 & 0.173 \\
MktRisk & 0.00 & 1.00 & 0.02 & 0.154 & 0.10 & 0.301 & 0.00 & 0.000 & 0.00 & 0.000 & 0.03 & 0.173 \\
DefCap & 0.00 & 1.00 & 0.05 & 0.216 & 0.00 & 0.000 & 0.00 & 0.000 & 0.00 & 0.000 & 0.02 & 0.142 \\
Conserv & 0.00 & 1.00 & 0.00 & 0.000 & 0.10 & 0.301 & 0.05 & 0.218 & 0.00 & 0.000 & 0.02 & 0.173 \\
C-cycl & .000 & 1.00 & 0.00 & 0.000 & 0.00 & 0.000 & 0.05 & 0.218 & 0.00 & 0.000 & 0.03 & 0.101 \\
NPLoans & .003 & .193 & 0.0728 & 0.0447 & 0.0718 & 0.0625 & 0.0203 & 0.0095 & 0.029 & 0.0202 & 0.0543 & 0.0472 \\
\hline
\end{tabular}

Source: Outputs of data processed by researcher.

To test the research hypothesis, step-wise regression analysis has been conducted and provided the following results, as shown in table 7:

Table 7. Effects of banking regulation on asset quality (asset quality categories)

\begin{tabular}{|c|c|c|c|}
\hline Item & All sample & Low-asset quality category & High-asset quality category \\
\hline \multirow[t]{2}{*}{$\alpha$} & 0.060 & 0.102 & 0.024 \\
\hline & $(11.969)^{* * *}$ & $(10.954)^{* * *}$ & $(6.251)^{* * *}$ \\
\hline \multirow[t]{2}{*}{ SA } & - & -0.045 & -0.049 \\
\hline & & $(-3.591)^{* * *}$ & $(-5.252)^{* * *}$ \\
\hline \multirow[t]{2}{*}{ BIA } & - & - & 0.063 \\
\hline & & & $(7.679)^{* * *}$ \\
\hline \multirow[t]{2}{*}{ AMA } & -0.040 & -0.040 & - \\
\hline & $(-3.315)^{* * *}$ & $(-2.166)^{* *}$ & \\
\hline \multirow[t]{2}{*}{$\mathrm{P} 2$} & - & - & $-\mathbf{0 . 0 2 0}$ \\
\hline & & & $(-2.088)^{* *}$ \\
\hline \multirow[t]{2}{*}{ Conserv } & 0.171 & 0.173 & - \\
\hline & $(3.839)^{* * *}$ & $(3.930)^{* * *}$ & \\
\hline \multirow[t]{2}{*}{ C-cycl } & -0.159 & - & - \\
\hline & $(-2.614)^{* *}$ & & \\
\hline $\mathbf{R}^{2}$ & 0.197 & 0.417 & 0.797 \\
\hline
\end{tabular}

Each cell contains the estimated parameters, with t-value between brackets, where * denotes p-value of $10 \%$, ** denotes $5 \%$ and *** denotes $1 \%$. 
Testing the significance of the effects of banking regulation implementation on asset quality could be illustrated as follows:

- For all sample: results show significant effects of AMA and Conserv at p-value of 0.01 and of C-cycle at p-value of 0.05 .

- For different asset quality groups: results indicate that asset quality of low-asset quality category may be affected by SA and Conserv at p-value of 0.01 and of C-cycle at p-value of 0.05 and by AMA at p-value of 0.05 . Besides, results show that asset quality of high-asset quality category may be affected by SA and BIA at p-value of 0.01 and of P2 at p-value of 0.05 .

Results don't seem to be robust, when comparing findings of all sample with those of high-asset quality category, while they seem to be robust for those of low-asset quality category, for AMA and Conserv effects.

To check the robustness of these results, the analysis has been conducted for 4 geographical groups, as summarized in table 8.

Table 8. Effects of banking regulation on asset quality (geographical groups)

\begin{tabular}{|c|c|c|c|c|}
\hline Item & Middle East \& Africa & Europe \& Central Asia & Latin America \& Caribbean & East Asia \& Pacific \\
\hline \multirow[t]{2}{*}{$\alpha$} & 0.101 & 0.087 & 0.018 & 0.042 \\
\hline & $(9.540)^{* * *}$ & $(6.605)^{* * *}$ & $(8.653)^{* * *}$ & $(6.006)^{* * *}$ \\
\hline \multirow[t]{2}{*}{ SA } & -0.044 & -0.076 & - & - \\
\hline & $(-3.340)^{* * * *}$ & $(-3.113)^{* * *}$ & & \\
\hline \multirow[t]{2}{*}{ BIA } & - & - & 0.011 & - \\
\hline & & & $(2.301)^{* *}$ & \\
\hline AMA & - & - & - & - \\
\hline \multirow[t]{2}{*}{$\mathrm{P} 2$} & - & - & - & -0.024 \\
\hline & & & & $(-2.328)^{* *}$ \\
\hline Conserv & - & $\mathbf{0 . 1 7 9}(3.566)^{* * *}$ & - & - \\
\hline \multirow[t]{2}{*}{ C-cycl } & 0.134 & - & - & - \\
\hline & $(4.349)^{* * *}$ & & & \\
\hline $\mathbf{R}^{2}$ & 0.232 & 0.528 & 0.218 & 0.349 \\
\hline
\end{tabular}

Each cell contains the estimated parameters, with t-value between brackets, where $*$ denotes p-value of $10 \%$, ** denotes $5 \%$ and $* * *$ denotes $1 \%$.

Testing the significance of the effects of banking regulation implementation on asset quality could be illustrated as follows:

- For Middle East \& Africa: results show significant effects of SA and C-cycle at p-value of 0.01.

- For Europe \& Central Asia: results show significant effects of SA and Conserv at p-value of 0.01.

- For Latin America \& Caribbean: results show significant effects of BIA at p-value of 0.05 .

- For East Asia \& Pacific: results show significant effects of P2 at p-value of 0.05 .

Results seem to be confusing again, as AMA and Conserv effects have not been appeared for the 4 above-shown categories (except Conserv effect for Europe \& Central Asia group). So, these effects don't seem to be robust.

Let's check the robustness of the results of different asset quality categories, by comparing them with those of different geographical groups. This could be illustrated as follows:

- SA and Conserv effects seem to be robust, when comparing findings of low-asset quality category with those of Middle East \& Africa and Europe \& Central Asia.

- BIA and P2 effects seem to be robust, when comparing findings of high-asset quality category with those of Latin America \& Caribbean and East Asia \& Pacific. 


\section{Summary and Concluded Remarks}

This paper attempts to investigate the effects of banking regulation on asset quality. This has been conducted using a sample of 14 countries from 1) Middle East \& Africa, 2) Europe \& Central Asia, 3) Latin America \& Caribbean and 4) East Asia \& Pacific, over the period from 2006 to 2012.

Asset quality is measured by "bank nonperforming loans to gross loans" according to The World Bank database regarding World Development Indicators, while banking regulation is measured by the "response to Basel implementation" according to FSI survey of July 2013.

Results indicate that implementation of SA "Standardized Approach" and Conserv "Capital conservation buffer" may affect "asset quality" for low-asset quality countries (Middle East \& Africa and Europe \& Central Asia groups), while implementation of BIA "Basic indicator approach " and P2 "Pillar2" may affect "asset quality" for high-asset quality ones (Latin America \& Caribbean and East Asia \& Pacific groups). So, results show that low-asset quality countries should concern with implementation of "Standardized Approach" and "Capital conservation buffer" while high-asset quality ones should concern with implementation of "Basic indicator approach "and "Pillar2".

"Standardized Approach", "Basic indicator approach "and "Pillar2" are techniques of Basel 2, while "Capital conservation buffer" is a tool of Basel 3. So, there is no evidence about the significance of Basel 2.5 techniques in enhancing asset quality. This point needs to be more elaborated using a larger sample and more robustness checks.

According to the results, implementation of "Standardized Approach", and "Pillar2" may enhance asset quality, as it reduces non-performing loans ratio, while implementation of "Basic indicator approach "and "Capital conservation buffer" may raise non-performing loans ratio. This point seems to be confusing and needs to be more elaborated using a larger sample, as applied on country level. This may encourage to elaborate regulatory effects on both of capital adequacy and asset quality. Does regulation enhance both of them, or there are some conflicts. If the same banking regulation has a positive effect on capital adequacy and a negative one on asset quality (or vice versa), it may be another story.

There is no evidence about the effectiveness of "Pillar 3" in enhancing asset quality. The effectiveness significance of "Pillar 3" needs to be rechecked using a larger sample and more robustness checks. Besides, this point could be elaborated in terms of the potential impacts of "Pillar 3" on other financial indicators, such as financial stability and systemic risk.

\section{References}

Acharya, V., Gale, D., \& Yorulmazer, T. (2009). Rollover Risk and Market Freezes. A working paper, New York University.

Altman, I. (1968). Financial Ratios, Discriminate Analysis and Prediction of Corporate Bankruptcy. Journal of Finance, 23(4), 589-609. http://dx.doi.org/10.1111/j.1540-6261.1968.tb00843.x

Amidu, M., \& Wolfe, S. (2009). Bank Competition, Diversification and Financial Stability. 22nd Australasian Finance and Banking Conference 2009. Retrieved from http://ssrn.com/abstract=1341863

Barth, J., Caprio, G., \& Levine, R. (2008). Bank Regulations Are Changing: For Better or Worse? World Bank Policy Research, Working Paper No 4646.

Basel Committee on Banking Supervision. (2013). Report to G20 Finance Ministers and Central Bank Governors on Monitoring Implementation of Basel III Regulatory Reform.

Beaver, W. (1966). Financial Ratios as Predictors of Failure. Journal of Accounting Research, 4, 71-111. http://dx.doi.org/10.2307/2490171

Beck, M., \& Keister, T. (2013). Liquidity Regulation and the Implementation of Monetary Policy. Bank for International Settlements, BIS Working Papers No 432.

Beck, T., Demirgüç-Kunt, A., \& Merrouche, Q. (2013). Islamic vs. Conventional Banking: Business model, Efficiency and Stability. Journal of Banking \& Finance, 37, 433-447. http://dx.doi.org/10.1016/j.jbankfin.2012.09.016

Berger, A., Klapper, L., \& Turk-Ariss, R. (2009). Bank Competition and Financial Stability. Journal of Financial Services Research, 35(2), 99-118. http://dx.doi.org/10.1007/s10693-008-0050-7

Buston, C. (2012). Active Risk Management and Banking Stability. http://dx.doi.org/10.2139/ssrn.2049390 
De Nicolò, G., Gamba, A., \& Lucchetta, M. (2011). Capital Regulation, Liquidity Requirements and Taxation in a Dynamic Model of Banking. Discussion Paper 2011-090, Tilburg University, Center for Economic Research.

Demirgüç-Kunt, A., \& Detragiache, A. (2011). Basel Core Principles and Bank Soundness Does Compliance Matter? Journal of Financial Stability, 7(4), 179-190. http://dx.doi.org/10.1016/j.jfs.2010.03.003

Dobravolskas, A., \& Seiranov, J. (2011). Financial Stability as the Goal of Post-Crisis Regulatory Reforms. Business Systems and Economics, 1(1), 101-114.

Financial Stability Institute, Bank for International Settlements. (2013). FSI Survey - Basel II, 2.5 and III Implementation. Retrieved from http://www.bis.org/fsi/fsiop2013.pdf

Gilbert, R., Meyer, A., \& Vaughan, M. (2002). Could a CAMELS Downgrade Model Improve Off-Site Surveillance? The Federal Reserve Bank of St. Louis, 47-64.

Maishanu, M. (2004). A Univariate Approach to Predicting Failure in the Commercial Banking Sub-Sector in Nigerian. Journal of Accounting Research, l(1).

Njoku, J. (2012). Surveillance Model of Going Concern in Banking. African Journal of Accounting, Auditing and Finance, 1(1). http://dx.doi.org/10.1504/AJAAF.2012.046126

Pastory, D., \& Mutaju, M. (2013). The Influence of Capital Adequacy on Asset Quality Position of Banks in Tanzania. International Journal of Economics and Finance, 5(2), 179-194. http://dx.doi.org/10.5539/ijef.v5n2p179

Pujal, A. (2001). Un Nouveau Ratio de Solvabilité en 2004. Banquemagazine, 622, 36-39.

Saunders, A., \& Cornett, M. (2003). Financial Institutions Management: A Risk Management Approach (4th ed.). McGraw- Hill.

Schaeck, C., \& Cihák, M. (2013). Competition, Efficiency, and Stability in Banking. Financial Management (forthcoming). http://dx.doi.org/10.1111/fima.12010

Schaeck, K., Cihák, M., \& Wolfe, S. (2007). Are Competitive Banking Systems More Stable? Journal of Money, Credit and Banking, 41(4), 711-734. http://dx.doi.org/10.1111/j.1538-4616.2009.00228.x

Schinasi, G. (2006). Safeguarding Financial Stability: Theory and Practice. Washington, D.C.: International Monetary Fund.

Schinasi, G. (2004). Defining Financial Stability. IMF Working Paper, International Capital Markets Department, International Monetary Fund, WP/04/187.

Sinkey, J. (2002). Commercial Bank Financial Management (6th ed.). N.Y.: Prentic Hall.

Spina, J. (2013). Banking Regulation and Basel III. Retrieved from http://ssrn.com/abstract=2248075

Swamy, V. (2011). Banking System Resilience and Financial Stability: An Evidence from Indian Banking. Retrieved from http://ssrn.com/abstract=2060744

Swamy, V. (2013). Determinants of Bank Asset Quality and Profitability- An Empirical Assessment. Munich Personal RePEc Archive, MPRA Paper No. 47513. Retrieved from http://mpra.ub.uni-muenchen.de/47513/

Tatom, J., \& Houston, R. (2011). Predicting Failure in the Commercial Banking Industry. Retrieved from http://mpra.ub.uni-muenchen.de/34608/

Tchana, F. (2008). Regulation and Banking Stability: A Survey of Empirical Studies. Retreived from http://ssrn.com/abstract=1150823

The World Bank. (2013). World Development Indicators. Retrieved from http://data.worldbank.org/indicator/FB.AST.NPER.ZS

Uhde, A., \& Heimeshoff, U. (2009). Consolidation in Banking and Financial Stability in Europe: Empirical $\begin{array}{lllll}\text { Evidence. Journal of Banking \& } & \text { Finance, 33(7), }\end{array}$ http://dx.doi.org/10.1016/j.jbankfin.2009.01.006

Wen, S., \& Jean Yu, J. (2013). Banking Stability, Market Structure and Financial System in Emerging Countries. Journal of Applied Finance \& Banking, 3(3), 1-13.

Wirnkar, A., \& Tanko, M. (2008). CAMELs and Banks' Performance Evaluation: The Way Forward. Retrieved from http://ssrn.com/abstract $=1150968$ 


\section{Copyrights}

Copyright for this article is retained by the author(s), with first publication rights granted to the journal.

This is an open-access article distributed under the terms and conditions of the Creative Commons Attribution license (http://creativecommons.org/licenses/by/3.0/). 